\title{
The skull of a fossil Prion (Aves: Procellariiformes) from the Neogene (Late Miocene) of northern Chile
}

\author{
Michel Sallaberry \\ David Rubilar-Rogers
}

Mario E. Suárez

Carolina S. Gutstein
Laboratorio de Zoología de Vertebrados, Universidad de Chile, Facultad de Ciencias,

Las Palmeras 3425, Ñuñoa, Santiago

msallabe@uchile.cl

drubilar@yahoo.com

Museo Paleontológico de Caldera, Av. Wheelwrigh 001, Caldera, Chile

museopaleontocaldera@gmail.com

sgcarolina@gmail.com

ABSTRACT

The fossil skull of a procellariid, Pachyptila sp., from Late Miocene marine sediments of the Bahía Inglesa Formation (Midde Miocene-Pliocene) of Northern Chile is described. The fossil is compared with extant species of the family Procellariidae. This discovery represents the first Neogene fossil record of the genus Pachyptila from South America.

Key words: Fossil Prion, Pachyptila, Procellariiformes, Neogene, Chile.

\section{RESUMEN}

El cráneo de un Petrel-paloma fósil (Aves: Procellariiformes) del Neógeno (Mioceno Tardío) del norte de Chile. Se describe un cráneo fósil de un procelláriido, Pachyptila sp., proveniente de sedimentos marinos del Mioceno Tardío de la Formación Bahía Inglesa (Mioceno Medio-Plioceno) del norte de Chile. El fósil es comparado con especies actuales de la familia Procellariidae. Este hallazgo representa el primer registro fósil neógeno del género Pachyptila en América del Sur.

Palabras claves: Petrel-paloma fósil, Pachyptila, Procellariiformes, Neógeno, Chile.

\section{INTRODUCTION}

Extant Procellariiformes comprise four families of seabirds: Diomedeidae (albatrosses), Hydrobatidae (storm-petrels), Pelecanoididae (diving-petrels), and Procellariidae (shearwaters, petrels and fulmars) (Harrison, 1983).
The procellariiform fossil records are scarce. The oldest procellariiform belongs to the Paleocene and lowest Eocene from North America (Olson and Parris, 1987; Feduccia and McPherson, 1993). The oldest material belongs to the family Diomedeidae (albatross) 
which has been reported from the Late Eocene of Antarctica (Tambussi and Tonni, 1998). Storm-petrels are known from the Late Miocene, and the only fossil record of diving-petrel comes from the Early Pliocene, both from South Africa (Olson, 1985a). The oldest known Procellariidae record is from the Early Oligocene of Iran (Peters and Hamedani, 2000). However, the history of this group reveals a hiatus of fossil records till the Early Pliocene, where the first occurrence is found in the Sub-Antarctic regions (Olson, 1985a, b, c).

In South America, fossil occurrences of this order are restricted to marine deposits from central Perú, southern Argentina and northern Chile (Walsh and Hume, 2001). Previously, isolated cranial remains of Chile were assigned to the Procellariiformes, family Diomedeidae, from the Bahía Inglesa Formation (Walsh and Hume, 2001). This paper reports the skull of a new fossil Procellariiformes from the Neogene of the Bahía Inglesa Formation. This find represents the first evidence of the genus Pachyptila in the fossil record of South America. Until now, the only fossil record of Pachyptila is restricted to one occurrence from the Late Pliocene of South Africa (Olson, 1985c) and Quaternary deposits in the Amsterdam island of the Indian Ocean (Worthy and Jouventin, 1999).

Up to date, only a few records of procellariiforms are known from the Neogene (Miocene) of South America, including from the Miocene of Patagonia (Olson, 1984), and the Late Miocene-Early Pliocene of Perú (Cheneval, 1993). This is mainly because the majority of the South American deposits containing fossil birds come from continental formations. Both the PiscoFormation inPerúand the BahíalnglesaFormation in Chile are equivalent in age and it is expected that it will be possible to compare faunistic similarities between the formations in the future. The paleogeographic and evolutionary implications of the Cenozoic bird fauna of the western portion of South America are in very early stages of research or are only beginning to be studied.

\section{GEOLOGY}

The fossil material reported here comes from a phosphatic conglomerate of the Bahía Inglesa Formation which represents the most important Neogene marine vertebrate deposit in Chile (Walsh and Naish, 2002; Suárez and Marquardt, 2003). The Bahía Inglesa Formation was defined by Rojo (1985) and emended by Marquardt (1999). The age of this unit ranges from the Middle Miocene to Early Pliocene, according to studies of shark teeth (Long, 1993; Suárez and Marquardt, 2003; Suárez et al., 2004), mollusks (Guzmán et al., 2000), micropaleontology (Herm, 1969; Marchant et al., 2000) and vertebrates (Marquardt, 1999; Suárez and Marquardt, 2003; Suárez et al., 2004). The Bahía Inglesa Formation is formed of over $42 \mathrm{~m}$ of siltstones, fine sandstones, shelly coquinas, pebble, and phosphatic beds, interpreted as deposited in a shallow marine setting accumulated within $10 \mathrm{~km}$ of the shore (Marchantetal., 2000). An important exposure of the Bahía Inglesa Formation occurs in an area of arid badlands $1 \mathrm{~km}$ inland of Bahía Inglesa, on the coast of the northern part of central Chile $\left(27^{\circ} 06^{\prime} 43.5^{\prime \prime} \mathrm{S}\right.$; $70^{\circ} 50^{\prime} 09.8^{\prime \prime} \mathrm{W}$ and $27^{\circ} 09^{\prime} 58.6^{\prime \prime} \mathrm{S} ; 70^{\circ} 52^{\prime} 32.4^{\prime \prime} \mathrm{W}$ ) (Fig. 1A). The closest settlement is Bahía Inglesa village, and the nearest town is Caldera, $10 \mathrm{~km}$ northeast of the study area, respectively. In this area the sequence was deposited in a series of grabens formed in the Mesozoic igneous basement (Godoy et al., 2003), today visible as a series of roughly NE-SW trending inliers. Walsh and Suárez (2005) recognized three lithostratigraphic members in this region; the coarse conglomeratic basal Morro Member (Unit 1 of Suárez et al., 2004), the phosphoritic Bahía Inglesa Formation of the Bonebed Member (Unit 2 of Walsh and Hume, 2001), and the fine sand and siltstone Lechero Member (Unit 3 of Walsh and Hume, 2001). A phosphatite (sensu Slansky, 1986) bonebed with a lateral extent of around $4 \mathrm{~km}^{2}$ occurs at the base of the Bahía Inglesa Formation Bonebed Member. This horizon comprises up to $77 \%$ (mostly fragmentary) vertebrate remains which, in addition to the Procellaridae fossil described here, also includes bony fish, reptiles, seabirds, sloths, seals, whales and dolphins (Walsh, 1999; Walsh and Hume, 2001; Walsh and Naish, 2002; Suárez and Marquardt, 2003; Suárez et al., 2004). The skull MPC 601 of this study, was recovered from this horizon. 

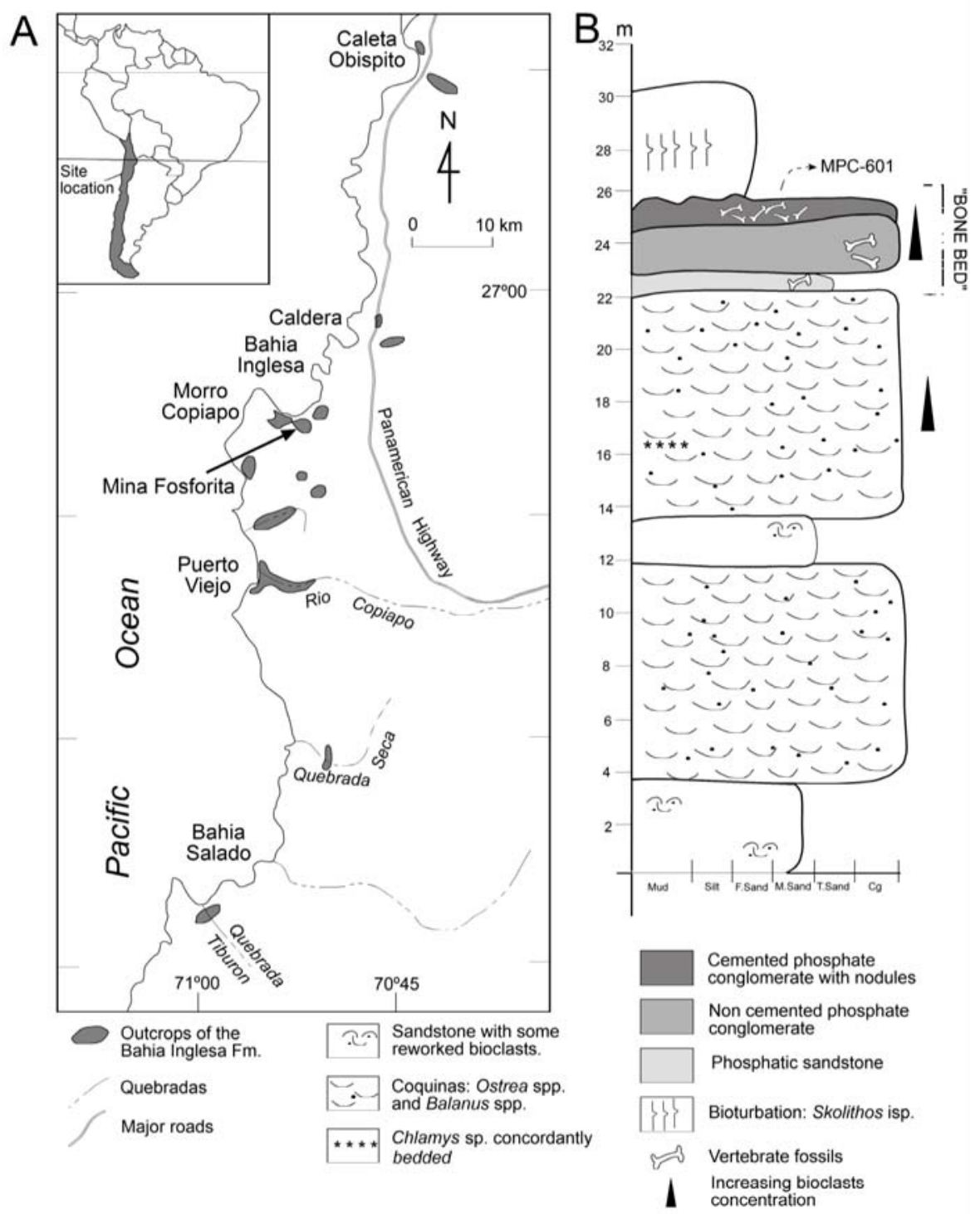

FIG. 1. A. Map showing fossiliferous outcrops of the Bahía Inglesa Formation in the Atacama Region, modified from Walsh and Suárez (2005); B. Stratigraphic column of the 'Mina Fosforita' site showing the bonebed, provenance of MPC-601. Abbreviations: Mud: mudstone; Silt: Siltstone; F. Sand: fine sandstone; M. Sand: medium sandstone; T. Sand: coarse sandstone; Cg: conglomerate.

\section{AGE}

The age of the Bahía Inglesa Formation bonebed can be constrained using radiometric data, and microfossil and vertebrate assemblages in the beds above and below the Bahía Inglesa Formation bonebed. Based on the study of the stratigraphy of the microfossils, the overlying Lechero Member is 4.5-2.6 million years (Tsuchi et al., 1988; Ibaraki,
1992, 1995). The shark assemblage of this member is characterized by the abundance of Carcharodon carcharias Linnaeus (Long, 1993), and the additional presence of Prionace glauca Linnaeus provides good evidence supporting a Pliocene age (Suárez and Marquardt, 2003). However, an ash layer occurs within the Lechero Member, approximately seven 
meters above the top of the Bahía Inglesa Formation Bonebed Member. This provides a K-Ar age of 7.6 \pm 1.3 million years (Marquardt et al., 2000; Godoy et al., 2003), indicating that the lower part of the Lechero Member is Late Miocene, and thus the bonebed would be no younger than Tortonian. However, the sharkfauna of the bonebed is dominated by Cosmopolitodus hastalis Agassiz while Carcharodon carcharias Linnaeus is present in low abundances. The teeth of these species have been used to differentiate Miocene from Pliocene sediments in South America (e.g., de Muizon and DeVries, 1985; Walsh and Hume, 2001; Walsh and Naish, 2002), but the presence of $C$. carcharias in Chilean Late Miocene sediments suggests that $C$. carcharias teeth are not a reliable indicator of age. A record of a Monachinae seal, Acrophoca sp., provides evidence of a Late Miocene age for the bonebed (Walsh and Naish, 2002) and cetaceans from the Pontoporiidae family are also consistent with this age. Unpublished data from one of the authors (C.S.G.) recognizes the same taxon, Brachydelphis mazeasi Muizon from Middle-Late Miocene beds at the Pisco Formation, Perú (de Muizon, 1988). In this article a Late Miocene (Tortonian) age for MPC-601 is proposed. The vertebrate assemblage from the unit 2 (Bonebed Member) is dominated by the fossil shark Cosmopolitodus hastalis, the most common species in the marine sediments of Middle-Late Miocene age in Chile (Suárez and Marquardt, 2003; Suárez et al., 2006). The abundance of fossils on this strata could be explained by the reworking of the phosphatic beds consistent with a transgressive-regressive model. Evidence of reworking was observed, like the state of preservation of the mainly broken fossils.

The diversity of fossils is also impressive in the Bahía Inglesa Formation bonebed; most vertebrate taxa from marine Miocene are well-represented here.

\section{MATERIAL AND METHODS}

The material consists of a complete braincase, belonging to the collection of the Museo Paleontológico de Caldera, under the catalogue number MPC-601 (Figs. 2, 3).

The skulls from differentspecies of Procellariiformes were studied from the Ornithological Collection of the Museo Nacional de Historia Natural, Santiago, and the Museo de Historia Natural, San Antonio. Specimens of Pachyptila belcheri (Mathews), Pachyptila vittata (=P. desolata Gmelin) were found in both museums sand Puffinus griseus (Gmelin). The authors also prepared skulls of the following species: Puffinus griseus, Pelecanoides garnotii (Lesson), Fregetta tropica (Gould) and Oceanites oceanicus (Kuhl), which were added to the collection of the Laboratorio de Zoología de Vertebrados (Universidad de Chile). Information on the genera Callonectris (Cory), Thalassoica (Gmelin), Pagodroma Bonaparte and Halobaena Bonaparte were obtained from a bank of photographic material of the Procellaride group (Seabirds Skull Gallery). A comparison of MPC-601 with extant skull material prepared in the laboratory of Pachyptila belcheri (Mathews), Pelecanoides garnotii, Fregetta tropica, Oceanites oceanicus and Puffinus griseus is provided in figure 3 ( $a$ y $b$ ).

The following skull measurements were obtained with a digital caliper $( \pm 0.01 \mathrm{~mm})$ as indicated in figure 2 .

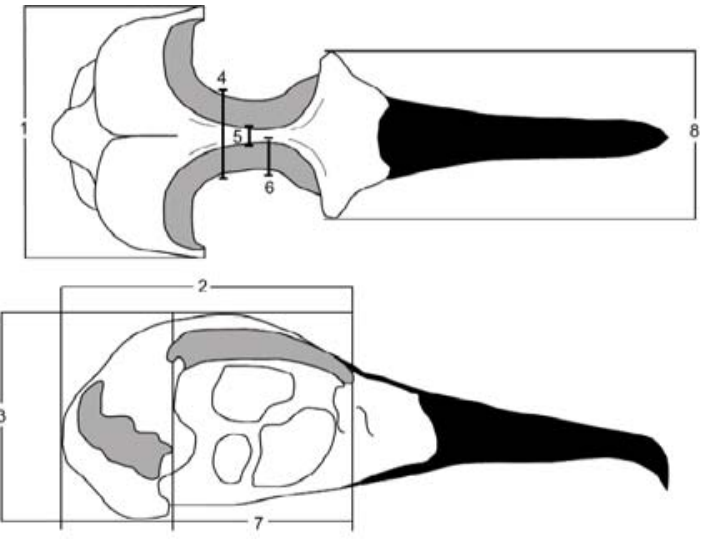

FIG. 2. Schematic drawing indicating location of skull measurements mentioned in the text. 1. Postorbital processes: maximum width of the skull at the postorbital processes; 2 . Nasofrontal hinge- basicranium: length between nasofrontal hinge and the dorsal edge of the basicranium; 3. Skull height: from the uppermost surface to the lowest point on the base of the skull; 4. Intergland width: measurement between the edge of the salt gland in the center of the ocular cavity; 5 . Interorbital width: width of the two salt glands at the frontal crest; 6 . Salt gland width: width between the edge at the center of the right salt gland; 7 . Orbital length: length along the antero- and post-orbital processes; 8 . Nasofrontal hinge width: width between the two antero-orbital processes. $\mathrm{NHW}(8) / \mathrm{PPW}(1)=$ relation between the naso-frontal hinge and the postorbital processes. 


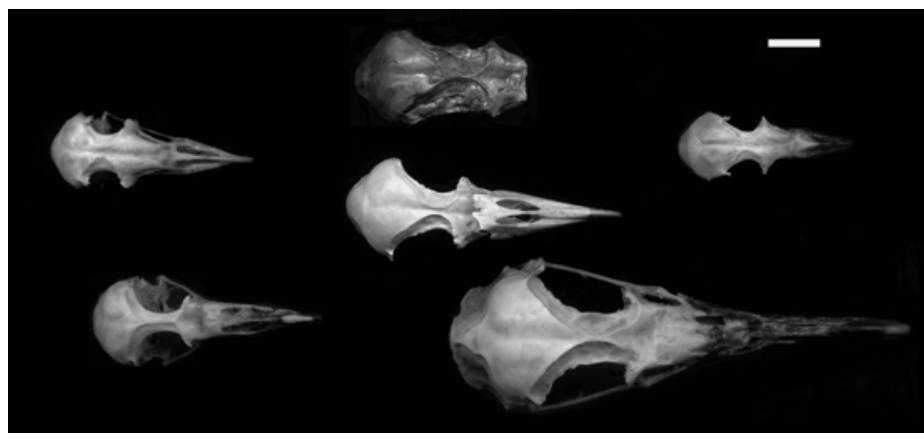

Upper left : Fregetta tropica (Gould)

Lower left : Pelecanoides garnotii(Lesson)

Upper center : Pachyptila sp. (MPC-601)

Middle center: Pachyptila belcheri (Mathews)

Upper right : Oceanites oceanicus (Kuhl)

Lower right : Puffinus griseus (Gmelin)

Upper left : Fregetta tropica (Gould)

Lower left : Pelecanoides garnotii(Lesson)

Upper center : Pachyptila sp. (Gmelin, MPC-601)

Middle center: Pachyptila belcheri (Mathews)

Upper right : Oceanites oceanicus (Kuhl)

Lower right : Puffinus griseus (Gmelin)

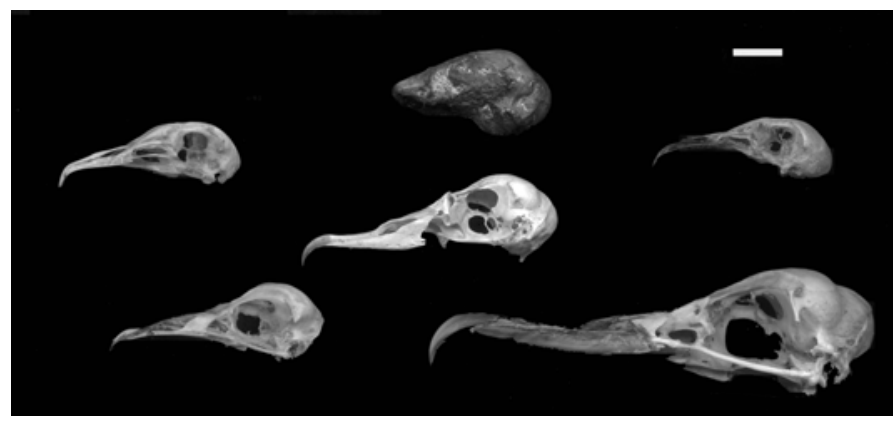

FIG. 3. A. Skulls of procellariids in dorsal view; B. Skulls of procellariids in lateral view. (Scale bar $=1 \mathrm{~cm})$.

\title{
SYSTEMATIC DESCRIPTIONS
}

\author{
Aves Linnaeus, 1758 \\ Order Procellariiformes Fürbringer, 1888 \\ Family Procellariidae Boie, 1822 \\ Genus Pachyptila Gmelin, 1789
}

Type species: Pachyptila desolata Gmelin, 1789. Living species, with circumpolar distribution in the southern ocean.

\section{Pachyptila sp.}

(Fig. 4)

Material: an incomplete skull numbered MPC-601, Late Miocene. Bahía Inglesa locality.

Description: in this incomplete skull (Fig. 4), the supraoccipital, exoccipitals, frontal, prefrontal and part of the complex ectethmoid-lacrimal, are clearly identifiable. The skull length is $36 \mathrm{~mm}$ from the nasofrontal hinge to the basicranium, and the maximum width at postorbital processes is $21 \mathrm{~mm}$. The well-preserved upper part of the skull is rounded, showing the two hemispheres of the cranium separated by a medial furrow. The skull is partially eroded on the edges, but it is possible to distinguish the basicranium and part of the rostrum, which is limited by the naso frontal hinge. Both the postorbital and orbital processes of the prefrontal bone are poorly developed. The supraorbital rings of the salt gland groove join together to form a dorsal crest (4 mm long) at the midline of the skull. The ventral region is partially covered with sediment, making it impossible to distinguish the area of the orbital septum. Nevertheless, it is possible to see part of the base of the temporal and the insertion of the quadrate bones. In dorsal view part of the foramen magnum, which is filled with sediment is observed. The groove for the depressor mandibulae muscle is projected posterodorsally, resulting in a separation of $7.85 \mathrm{~mm}$ in the parietal bone. In the dorsal view the grooves are not evident. The main measurements of this fossil and other possible relative species are on table 1. 

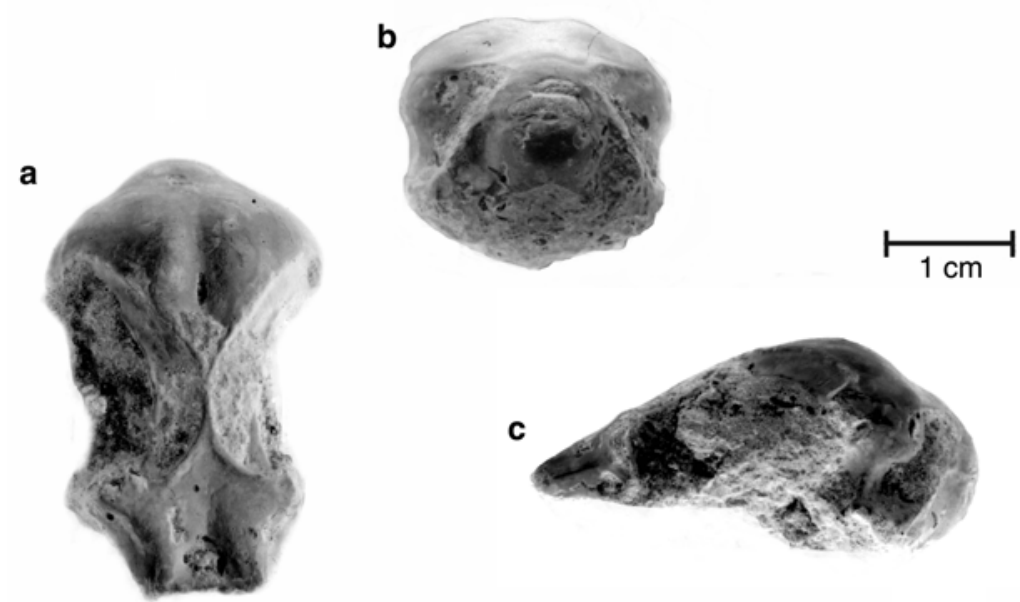

FIG. 4. Pachyptila sp. MPC-601, Late Miocene (Tortonian), Bahía Inglesa Formation, Caldera. a. dorsal view; b. posterior view; c. left lateral view.

\section{DISCUSSION}

In the specimen MPC-601, the two grooves of the depressor mandibulae muscles are projected posterodorsally and noticeably separated by the parietal bone. This particular characteristic is present in almost all the species of the genus Pachyptila (except $P$. vittata Gmelin), Pelecanoides, Fregetta and Oceanites. On the contrary, in Pachyptila vittata, Callonectris and Puffinus the two grooves for the insertion of the depressor mandibulae muscles are almost connected by a very narrow edge, at the rear of the skull, evident in dorsal view.

On MPC-601 the supraorbital furrows are medially connected, forming a crest at the midline of the skull which is also present in Pelecanoides and Pachyptila vittata. Other living species of Pachyptila do not have this feature, displaying instead a rather wide middle bar between the supraorbital furrows. The same condition is evident for other genera such as Thalassoica, Pagodroma and Halobaena, in which this bar is even larger. Nevertheless, in MPC-601 the contact along the supraorbital furrows is smaller than in Pelecanoides and Pachyptila vitatta, comprising about $1 / 10$ of the length between the nasofrontal hinge and the posterior edge of the basicranium, in contrast to these two genera and species, which comprise only $1 / 5$ of the length.

Using the ratio of the relation between the nasofrontal hinge and the postorbital processes (NHW(8)/PPW(1), it was found that MPC-601 is similar to Pachyptila belcheri (mean ratio 0.82 and 0.74 respectively). The other species (Pachyptila vittata, Pelecanoides garnotii, Puffinus griseus,
Puffinus creatopus, Pterodroma cookiy Pterodroma externa) show a lower ratio (<0.6).

The phylogenetic hypothesis based on molecular evidences of living Procellariiformes, shows that the genera Oceanites and Oceanodroma are the sister group of a larger clade composed by Pelecanoides, Macronectes, Pterodroma, Pachyptila, Thalassoica, Puffinus and Callonectris plus the clade Diomedeidae. In this clade, the genus Pelecanoides represents the basal group, and the genus Pachyptila shows major affinity with Thalassoica, Puffinus y Calonectris (Sibley and Ahlquist, 1990). However, in MPC-601, the morphological characters are related to both, Pelecanoides and Pachyptila. Based on this information there is no relationship between the affinities obtained with the molecular evidence and morphological characters. Then, the morphological characters present in Pachyptila and Pelecanoides maybe convergent characters. With this in mind, any relation of affinity between MPC-601 with Pelecanoides or Pachyptila could be possible. Nevertheless, the ratio (NHW/PPW) estimated above indicates that the fossil form MPC-601 has a stronger affinity to Pachyptila than Pelecanoides. This leads us to refer MPC-601 to Pachyptila sp. Then, MPC-601 represents the first record of nondiomedeid procellariiforms of the genus Pachyptila from the Late Miocene of the Bahía Inglesa Formation in Chile, and the first occurrence of this genus in the Neogene of the Southern Hemisphere, which is in concordance with the actual distribution of the genera. 
TABLE 1. PRINCIPAL SKULL MEASUREMENTS OF MPC-601 AND OTHER SPECIES OF PROCELLARIIFORMS.

\begin{tabular}{|c|c|c|c|c|c|c|c|c|c|}
\hline Taxa & \multicolumn{8}{|c|}{ Measurements* } & NHW/PPW \\
\hline MPC-601 & 20.47 & 35.46 & 18.7 & 8.2 & 0 & 4.3 & 18.4 & 16.78 & 0.82 \\
\hline Pachyptila vittata & 23.9 & 37.13 & 20 & 5.39 & 0 & 4.06 & 16.7 & 13.9 & 0.58 \\
\hline Pachyptila belcheri & 18.9 & 33.15 & 16.9 & 7.4 & 3.01 & 3.84 & 14.5 & 14.93 & 0.79 \\
\hline Pachyptila belcheri & 20.48 & 34.22 & 18.9 & 7.2 & 3.3 & 3.52 & 14.2 & 15.94 & 0.78 \\
\hline Pachyptila belcheri & 19.85 & 33.95 & 17 & 7.15 & 2.5 & 3.28 & 14 & 15.95 & 0.8 \\
\hline Pachyptila belcheri & 22.27 & 33.55 & 16.8 & 7.6 & 2.57 & 3.8 & 15.3 & 14.49 & 0.63 \\
\hline Pelecanoides garnotii & 20.46 & 29.11 & 19.4 & 5. 07 & 0 & 2.6 & 14.1 & 9.98 & 0.49 \\
\hline Pelecanoides garnotii & 18.23 & 25.45 & 16.6 & 3.63 & 0 & 2.55 & 12.2 & 10.59 & 0.58 \\
\hline Puffinus griseus & 30.4 & 44.67 & 22.2 & 9.94 & 0.53 & 4.67 & 18.5 & 11.48 & 0.38 \\
\hline
\end{tabular}

* as described in methodology

\section{ACKNOWLEDGEMENTS}

We would like to thank S.A. Walsh (University of Portsmouth, UK), J. Noriega (Centro de Investigación Científica y de Transferencia Tecnológica a la Producción (CICYTTP, Diamante, Argentina)), C. Tambussi (Universidad Nacional de La Plata, Argentina), E. Pérez d'A. and M. Suárez (SERNAGEOMIN), for the valuable and critical comments. Mr. J.L. Brito (Museo de Arqueología y Ciencias Naturales de San Antonio, Chile) and Mr. J.C. Torres-Mura (curator of the Museo Nacional de Historia Natural, Santiago, Chile) for their generosity and for allowing us to study their collections. We also would like to thank M. Stucchi and J. Apolín from the Museo de Historia Natural, Universidad Nacional Mayor de San Marcos, for sharing their experience with us. Finally we would like to thank our friend and colleague M. Novacek (American Museum of Natural History, New York), for comments on the paper.

\section{REFERENCES}

Boie, H. 1822. Isis (oder Encyclopaedische Zeitung, von Oken) 10, 11: col. 549.

Cheneval, J. 1993. L'avifaune miopliocene de la Formation Pisco (Pérou). Etude préliminaire. In Paléontologie et Stratigraphie d'Amérique Latine. Table Ronde Européenne (Gayet, M.; coordinateur). Documents Laboratoire Géologique Lyon 125: 85-95.

de Muizon, C. 1988. Les Vertebrés fossils de la Formation Pisco. Les odontocetes du Miocene. Éditions Recherche sur les civilizations 78: 1-244.

de Muizon, C.; DeVries, T.J. 1985. Geology and paleontology of late Cenozoic marine deposits in the Sacaco area (Perú). Geologische Rundschau 74 (3): 547-563.

Feduccia, A.; McPherson. 1993. A petrel-like bird from the late Eocene of Louisiana: earliest record of the order Procellariiformes. Proceedings of the Biological Society of Washington 106: 749-751.
Fürbringer, M. 1888. Untersuchungen zur Morphologie und Systematik der Vögel zugleich ein Beitrag zur Anatomie der Stütz und Bewegungsorgane. II Allgemeiner Amsterdam: Theil. Verlag von Holkema: 49 p.

Gmelin, J.F. 1789. Systema Naturae per regna tria naturae, secundum classes, ordines, genera, species; cum characteribus, differentiis, synonymis, locis. Editio decimo tertia, aucta, reformata 3 in 9 parts: 1788-93, Lipsiae. Systema Naturae Linné: 1033-1516.

Godoy, E.; Marquardt, C.; Blanco, N. 2003. Carta Caldera, Región de Atacama. Servicio Nacional de Geología y Minería, Carta Geológica de Chile, Serie Geología Básica 76: 39 p.

Guzmán, N.; Marquardt, C.; Ortlieb, L.; Frassinetti, D. 2000. La malacofauna neógena y cuaternaria del área de Caldera $\left(27^{\circ}-28^{\circ} \mathrm{S}\right)$ : especies y rangos bioestratigráficos. In Congreso Geológico Chileno, No. 9, Actas 1: 476 -481. Puerto Varas. 
Harrison, P. 1983. Seabirds: an identification guide. Houghton Mifflin Co: 448 p. Boston.

Herm, D. 1969. Marines Pliozän und Pleistozän in Nord und Mittel Chile unter besonderen Berücksichtigung der Entwicklung der Mollusken-Faunen. Zitteliana 2: 1-159.

Ibaraki, M. 1992. Geologic age of biosiliceous sediments in Perú and Chile based upon planktonic foraminifera. Revista Geológica de Chile 19 (1): 61-66.

Ibaraki, M. 1995. Neogene chronostratigraphy of biosiliceous sediments on the Pacific coast of South America based on planctonic foraminifera. Reports of the Faculty of Science, Shizuoka University 29: 63-71.

Linnaeus, C. 1758. Systema Naturae. Edition Systema naturae per Regna tria naturae, secundum classes, ordines, genera, species, cum characteribus, differentiis, synonymis, locis. 10 ${ }^{\text {th }}$ Edition 1: $824 \mathrm{p}$.

Long, D.J. 1993. Late Miocene and Early Pliocene fish assemblages from the north central coast of Chile. Tertiary Research 14: 117-126.

Marchant, M.; Marquardt, C.; Blanco, N.; Godoy, E. 2000. Foraminíferos del área de Caldera $\left(26^{\circ} 45-28^{\circ} \mathrm{S}\right)$ y su utilización como indicadores cronoestratigráficos del Neógeno. In Congreso Geológico Chileno, No. 9, Actas 1: 499-503. Puerto Varas.

Marquardt, C. 1999. Neotectónica de la franja costera y aportes a la geología regional entre Caldera y Caleta

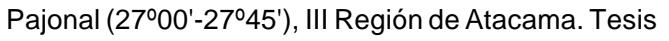
de Magíster (Inédito), Universidad de Chile, Departamento de Geología: 297 p.

Olson, S.L. 1984. Evidence of a large albatross in the Miocene of Argentina (Aves: Diomedeidae). Proceedings of the Biological Society of Washington 97: 741-743.

Olson, S.L. 1985a. The fossil record of birds. In Avian Biology (Farner, D.S.; King, J.R.; Parkes, K.C.; editors). Academic Press 8: 79-252. New York.

Olson, S.L. 1985b. Early Pliocene Procellariiformes (Aves) from Langebaanweg, South-western Cape Province, South Africa. Annals of the South African Museum 95: 123-145.

Olson, S.L. 1985c. An early Pliocene marine avifauna from Duinefontein, Cape Province, South Africa. Annals of the South African Museum 95: 147-164.

Olson, S.L.; Parris, D.C. 1987. The Cretaceous birds of New Jersey. Smithsonian Contributions to Paleobiology 63: 1-22.

Peters, D.S.; Hamedani, A. 2000. Frigidafons babaheydariensis n. sp., ein Sturmvogel aus dem Oligozan des Iran (Aves: Procellariidae). Senckenbergiana Lethaea 80: 29-37.

Rojo, M. 1985. Un aporte al conocimiento del Terciario marino: Formación Bahía Inglesa. In Congreso
Geológico Chileno, No. 4, Actas, 1: 514-532. Antofagasta.

Slansky, M. 1986. Geology of sedimentary phosphates. Elsevier Science Publications: 210 p. New York.

Sibley, C.G.; Ahlquist, J.E. 1990. Phylogeny and classification of birds. A study in Molecular Evolution. Yale University Press: 976 p. New Haven and London.

Suárez, M.E.; Marquardt, C. 2003. Revisión preliminar de las faunas de peces elasmobranquios del Mesozoico y Cenozoico de Chile y comentarios sobre su valor cronoestratigráfico. In Congreso Geológico Chileno, No. 10, Sección temática 3, CD ROM. Concepción.

Suárez, M.E.; Lamilla, J.; Marquardt, C. 2004. Peces Chimaeriformes (Chondrichthyes, Holocephali) del Neógeno de la Formación Bahía Inglesa (Región de Atacama, Chile). Revista Geológica de Chile 31 (1): 105-117.

Suárez, M.E.; Encinas, A.; Ward, D. 2006. An Early Miocene elasmobranch fauna from the Navidad Formation, Central Chile, South America. Cainozoic Research 4 (1-2): 3-18.

Tambussi, C.; Tonni, E. 1998. Un Diomedeidae (Aves: Procellariiformes) del Eoceno tardío de la Antártida. In Jornadas Argentinas de Paleontología de Vertebrados, No. 5, Resúmenes: 34-35. La Plata.

Tsuchi, R.; Shuto, T.; Takayama, T.; Fujiyoshi, A.; Koizumi, I.; Ibaraki, M.; Martínez, R.P. 1988. Fundamental data on Cenozoic biostratigraphy of Chile. In Reports of Andean studies (Tsuchi, R.; editor). Shizuoka University-Trans-Pacific Correlation of Cenozoic Geohistory. Kofune Printing 2: 1-108. Shizuoka.

Walsh, S.A. 1999. A new Mio-Pliocene marine bone-bed from north-central Chile. In Annual Meeting of Vertebrate Paleontology, No. 50, Denver, Colorado. Journal of Vertebrate Paleontology 19 (3): 82A-83A.

Walsh, S.A.; Hume, J.P. 2001. A new Neogene marine avian assemblage from north-central Chile. Journal of Vertebrate Paleontology 21 (3): 484-491.

Walsh, S.A.; Naish, D. 2002. Fossil seals from late Neogene deposits in South America: a new pinniped (Carnivora, Mammalia) assemblage from Chile. Palaeontology 45 (4): 821-842.

Walsh, S.A.; Suárez, M. 2005. First post-Mesozoic record of Crocodyliformes from Chile. Acta Palaentologica Polonica 50 (3): 595-600.

Worthy, T.H.; Jouventin P. 1999. The fossil avifauna of Amsterdam Island, Indian Ocean. In Avian Paleontology at the close of $20^{\text {th }}$ Century (Olson, S.; editor). Proceedings of the International Meeting of the Society of Avian Paleontology and Evolution No. 4. Smithsonian Contributions to Paleobiology 89: 39-65. Washington. 